\title{
Determination of Knowledge, Attitudes and Behaviors towards Traditional and Complementary Medicine in Patients Applying to Pamukkale University Medical Faculty Hospital Polyclinics
}

\author{
Guliz Aydemir Acar ${ }^{1 *}$, iD Bilge Betul Kilic², iD Nurhan Meydan Acimis² iD \\ ${ }^{1}$ Nigde Provincial Health Directorate, Nigde, Turkey \\ 2 Department of Public Health, Medicine Faculty, Pamukkale University, Denizli, Turkey \\ * Corresponding Author: Guliz Aydemir Acar, e-mail: glz.1986@outlook.com
}

Received: 11.10.2021 Accepted: 30.11.2021

\begin{abstract}
Objective: The aim of research was to investigate the attitudes and behaviors towards traditional and complementary medicine methods, the use of which has increased in recent years, in individuals admitted to the hospital.

Material-Method: The descriptive study was performed by applying a questionnaire to 276 people. The questionnaire included questions about the sociodemographic characteristics of the participants, their knowledge, attitudes and behaviors about traditional complementary medicine methods, and the Complementary, Alternative, and Conventional Medicine Attitude Scale. Data were analyzed with the Statistical Package for the Social Sciences version 15. Chi-square test, Mann-Whitney $\mathrm{U}$ and Kruskall-Wallis $\mathrm{H}$ tests were used in the comparison of traditional and complementary medicine attitudes and behaviors with sociodemographic characteristics. $\mathrm{p}<0.05$ was considered significant.

Results: $33 \%$ of respondents had applied at least one traditional complementary medicine method. The most commonly used methods were cupping $(n=40)$, phytotherapy $(n=34)$ and acupuncture $(n=17)$. The mean score of scale was found to be $109.05 \pm 15.44$. The mean score of the individuals aged 45 and over is higher than the other ages and is $102.7 \pm 17.2$ ( $\mathrm{p}<0.048)$. A statistically significant difference was found between the use of at least one traditional and complementary method and the variables of age, marital status, place of residence for the longest time, and perceived health ( $\mathrm{p}<0.05)$.

Conclusion: TCM methods are known to the majority of people who visit polyclinics. Their attitudes towards traditional and complementary medicine are quite close to positive. Physicians should question whether their patients use traditional methods.
\end{abstract}

Keywords: Complementary Medicine, Traditional Medicine, Knowledge, Attitudes, Practice

\section{INTRODUCTION}

According to World Health Organization (WHO), traditional medicine is the sum total of the knowledge, skill and practices based on the beliefs, beliefs and experiences traditional to different cultures, whether explicable or not, used in the maintenance of health as well as in the prevention, diagnosis, improvement or treatment of physical and mental illnesses. WHO has defined complementary medicine as: 'a broad set of healthcare practices that are not part of that country's own tradition or conventional medicine and are not fully integrated into the dominant healthcare system ${ }^{1,2}$. As a result of the discussions, it was decided that these methods could not be an alternative to medicine, but could only be complementary to the treatment, and the definition of "traditional and complementary medicine" came to the fore, based on the definition of $\mathrm{WHO}^{3}$. Traditional and complementary medicine (TCM) methods are classified as "alternative whole medical systems" (homepathy, acupuncture, etc.), "mind-body interventions" (hypnotherapy, yoga, etc.), "biological-based therapies" (probiotics, antioxidants, herbs), "manipulative body-based methods" and "energy therapies" 4,5 .

Although the clinical efficacy of many TCM methods is controversial because of a lack of scientific evidence, the use of TCM has increased significantly worldwide, especially in the last 20 years ${ }^{6,7}$. Studies show that the frequency of TCM use varies between 9.8-76\% worldwide ${ }^{7}$. Many individuals resort to TCM methods for the treatment of serious physical and mental diseases, 


\author{
Volume: 2 Issue: 3 \\ Year: 2021 \\ DOI: $10.53811 /$ ijtcmr. 1008027
}

International Journal of Traditional and Complementary

Medicine Research
Publisher

Duzce University especially diabetes, hypertension, cancer, musculoskeletal system diseases and dermatological problems ${ }^{6,8}$. Sometimes patients may prefer these methods first without going to the health institution, and sometimes they turn to these methods to support their medical treatment ${ }^{8}$. The fact that TCM methods are individualoriented and their holistic approach, which takes into account not only physical health but also mental and social well-being, has made these methods trustworthy by the society ${ }^{4}$. The WHO supports the integration of proven TCM methods into national health systems ${ }^{9}$. The frequency of use of TCM in Turkey has been reported as $22.1 \%$, and these methods have not yet been integrated into the national health system ${ }^{10}$. TCM services are carried out by physicians and dentists (only in the field of dentistry) who have practice certificates in practice centers authorized by the Ministry. Health professionals with basic education can participate in the practice under the supervision of certified physicians. With the Regulation on Traditional and Complementary Medicine Practices by the Ministry of Health, the principles of the practices, who can do it, the qualifications of the places where the practice will be made, the drugs that must be kept in the practice centers and the inspection principles have been determined ${ }^{11}$.

The factors affecting the use of TCM are various. Sociodemographic factors, income level, type and severity of the disease, dissatisfaction with modern medicine, limited health care access, cultural beliefs, long-term use of TCM methods, perceived usefulness and safety of these methods, accessibility of TCM methods and being affected by social networks are considered among the reasons why TCM methods are preferred 4,6,7,8,12. In the literature, the main reasons that keep individuals from using these methods are reported as lack of scientific evidence for TCM methods, disbelief in their effectiveness and safety, and not performing the applications under hygienic conditions 7 . The reasons for using TCM vary from country to country, while Western societies use these methods to keep their health under control, these methods are used in African countries due to the problems experienced in accessing professional health personnel and the affordability and accessibility of TCM methods. Asian societies are influenced by social networks and turn to TCM methods. Dissatisfaction with conventional medicine in South American countries is the main reason for using TCM $^{7,9}$. There are many studies to determine the frequency of use of these methods in specific disease conditions and the knowledge and attitudes of health professionals about TCM. The number of studies investigating the knowledge, attitudes and behaviors of people applying to a health institution towards TCM applications is limited.

The aim of this study is to determine the knowledge, attitudes and behaviors of people who applied to selected polyclinics of a university hospital towards TCM.

\section{MATERIALS AND METHODS}

This research is a descriptive type epidemiological study. The population of the study consisted of individuals who applied to four selected polyclinics (internal diseases, family medicine, physical therapy and rehabilitation and dermatology) of the Pamukkale University Medical Faculty Hospital. According to the sample size calculation formula of the Open Epi program, the population size of which is unknown, the frequency was accepted as $50 \%$ and the type 1 error level was $5 \%$, and the sample size to represent the universe was calculated as 384 with $80 \%$ power and $95 \%$ confidence interval $(\mathrm{p}=0.50$, alpha $=0,05, \mathrm{~d}=0.05)$. The research was carried out between January 30-February 26, 2019. The data collection tool of the research is a questionnaire consisting of 59 questions, created by the researchers by scanning the literature. In the questionnaire form, there are 9 questions about the sociodemographic characteristics of the participants, 6 questions about the general health characteristics, 17 questions about the level of knowledge and behavior of traditional and complementary medicine. In the survey, the practices mentioned in the Regulation on Traditional and Complementary Medicine Practices published in the Official Gazette No. 29158 on 27.10 .2014 were questioned, while other traditional methods used among the public were not included. There are 15 TCM methods whose implementation principles are determined by the relevant regulation. These are acupuncture, apitherapy, phytotherapy, hypnosis, leech therapy, homeopathy, chiropractic, cupping, maggot debridement therapy, mesotherapy, prolotherapy, osteopathy, ozone application, reflexology and musicotherapy (11). The data of the research were collected between 1-15 February 2019 by filling in the questionnaire form 
Volume: 2 Issue: 3

Year: 2021

DOI: $10.53811 / \mathrm{ijtcmr} .1008027$
International Journal of Traditional and Complementary

Medicine Research
Publisher

Duzce University by people who volunteered to participate in the research. The Complementary, Alternative, and Conventional Medicine Attitude Scale (CACMAS) consisting of 27 questions was used to determine the attitudes of the participants towards traditional and complementary medicine. The scale consists of 3 sub-factors: Philosophical congruence with complementary and alternative medicine, dissatisfaction with conventional medicine, and holistic balance. The scale is 7point Likert type ( $1=\mathrm{I}$ strongly disagree, $7=\mathrm{I}$ strongly agree). Questions 1, 4, 8, 9 and 26 are reverse coded. A score between 27-189 can be obtained from the scale. A high score from the scale indicates a positive attitude towards traditional and complementary medicine. The Turkish validity and reliability study of the scale developed by McFadden et al. was performed by Köse et al. ${ }^{13}$ (Cronbach's alpha: 0.808). Ethical approval for this study was obtained from Pamukkale University Faculty of Medicine NonInvasive Clinical Research Ethics Committee for the study. Required institutional permission has been obtained. Verbal consent was obtained from the participants.

\section{Statistical analysis}

Statistical Package for the Social Sciences (SPSS) version 17 was used for data analysis. Descriptive statistics are given by calculating mean, standard deviation, frequency and percentage. The compatibility of continuous variables with normal distribution was evaluated with KolmogorovSmirnov and Shapiro Wilk Tests. Since the normal distribution conditions were not met, Mann-Whitney U test and Kruskal-Wallis H test were used to compare the scale means. Factors associated with performing at least one traditional application were compared using the Pearson Chi-square test. Statistical significance level was considered significant if $\mathrm{p}<0.05$.

\section{RESULTS}

Overall $276(72.0 \%)$ people participated in the research. The mean age of the participants in the study was $37.6 \pm 14.1$ years. $58.9 \%$ of the participants were women, while $83.7 \%$ of the participants had a high school or higher education level and $36.7 \%$ of the participants had a chronic disease. The sociodemographic characteristics of the participants in the study are shown in Table 1.

Table 1. Sociodemographic characteristics of the participants

\begin{tabular}{|c|c|c|c|}
\hline & & $\mathbf{n}$ & $\%$ \\
\hline \multirow{3}{*}{ Age } & $18-24$ & 72 & 26.1 \\
\hline & $25-44$ & 112 & 40.6 \\
\hline & $\geq 45$ years & 92 & 33.3 \\
\hline \multirow{2}{*}{ Gender } & Female & 162 & 58.9 \\
\hline & Male & 113 & 41.1 \\
\hline \multirow{2}{*}{ Education level } & Middle school and below & 45 & 16.3 \\
\hline & High school and above & 231 & 83.7 \\
\hline \multirow{3}{*}{ Income } & Income less than expenses & 83 & 30.5 \\
\hline & Income equals expense & 135 & 49.6 \\
\hline & Income more than expenses & 54 & 19.9 \\
\hline \multirow{3}{*}{ Marital status } & Married & 119 & 43.1 \\
\hline & Single & 131 & 47.5 \\
\hline & Divorced/Widowed/Separate & 26 & 9.4 \\
\hline \multirow{3}{*}{ Family type } & Nuclear family & 230 & 83.9 \\
\hline & Extended family & 31 & 11.3 \\
\hline & Broken family & 13 & 4.7 \\
\hline \multirow{3}{*}{ Longest lived place } & Province & 186 & 67.6 \\
\hline & District & 67 & 24.4 \\
\hline & Town/Village & 22 & 8.0 \\
\hline \multirow{3}{*}{ Perceived health } & Excellent/Very good & 88 & 31.9 \\
\hline & Good/Medium & 186 & 67.4 \\
\hline & $\mathrm{Bad}$ & 2 & 0.7 \\
\hline \multirow{2}{*}{ Chronic disease } & Yes & 101 & 36.7 \\
\hline & No & 174 & 63.3 \\
\hline \multirow{4}{*}{ Outpatient clinic applied } & Internal medicine & 88 & 31.9 \\
\hline & Family medicine & 23 & 8.3 \\
\hline & Dermatology & 71 & 25.7 \\
\hline & Physical therapy and rehabilitation & 94 & 34.1 \\
\hline
\end{tabular}


Volume: 2 Issue: 3

Year: 2021

DOI: $10.53811 /$ ijtcmr.1008027
International Journal of Traditional and Complementary

Medicine Research
Publisher

Duzce University
The frequency of participants who heard TMC modalities was $85.9 \%$; $40.4 \%$ of participants got information about TCM; source of information was television/radio/internet with a frequency of 28.3\%. The participants stated that TCM applications were beneficial with a frequency of $36.6 \%$. They stated that they applied at least one TCM method with a frequency of $33.0 \%$. It was found that the purpose of the applications was relaxation with a frequency of $66.3 \%$ and treatment with a frequency of $25.8 \% ; 18.0 \%$ of participants who had TCM application stated that they benefited completely, $71.9 \%$ benefited partially, $10.1 \%$ had no benefit from the application. The knowledge, attitudes and behaviors of the participants towards TCM applications are shown in Table 2. The methods most frequently applied by the participants of the study are cupping method $(n=40)$, phytotherapy $(n=34)$ and acupuncture $(n=17)$.

Table 2. Participants' knowledge, attitude and behavioral characteristics towards TCM applications

\begin{tabular}{|c|c|c|c|}
\hline & & $\mathbf{n}$ & $\%$ \\
\hline \multirow{2}{*}{ Hearing the methods } & Yes & 237 & 85.9 \\
\hline & No & 39 & 14.1 \\
\hline \multirow{2}{*}{$\begin{array}{l}\text { Getting information about TCM } \\
\text { modalities }\end{array}$} & Yes & 111 & 40.4 \\
\hline & No & 164 & 59.6 \\
\hline \multirow{7}{*}{ Information source* } & Specialist doctor & 14 & 5.1 \\
\hline & Family doctor & 2 & 0.7 \\
\hline & Pharmacist & 2 & 0.7 \\
\hline & Nurse & 1 & 0.4 \\
\hline & Television/Radio/Internet & 78 & 28.3 \\
\hline & Book/Magazine/Newspaper & 37 & 13.4 \\
\hline & Neighbor/Relative/Frien & 60 & 21.7 \\
\hline \multirow{4}{*}{$\begin{array}{l}\text { Thoughts on the usefulness of } \\
\text { TCM }\end{array}$} & Beneficial & 100 & 36.6 \\
\hline & Damaging & 14 & 5.1 \\
\hline & Neither beneficial nor harmful & 69 & 25.3 \\
\hline & No idea & 90 & 33.0 \\
\hline \multirow{2}{*}{$\begin{array}{l}\text { Useing at least one of the TCM } \\
\text { modalities }\end{array}$} & Yes & 91 & 33.0 \\
\hline & No & 185 & 67.0 \\
\hline \multirow{4}{*}{ The purpose of applying TCM } & Cosmetic & 5 & 5.6 \\
\hline & Protection & 2 & 2.2 \\
\hline & Relaxation & 59 & 66.3 \\
\hline & Treatment & 23 & 25.8 \\
\hline \multirow{2}{*}{ Application time } & Before going to the doctor & 63 & 71.6 \\
\hline & After going to the doctor & 25 & 28.4 \\
\hline \multirow{5}{*}{ Place of application } & Public hospital & 3 & 3.4 \\
\hline & Private hospital & 5 & 5.7 \\
\hline & Private health institution & 18 & 20.7 \\
\hline & House & 53 & 66.7 \\
\hline & Other & 3 & 3.4 \\
\hline \multirow{6}{*}{ Person making the application* } & Doctor & 13 & 4.7 \\
\hline & Nurse/Midwife & 2 & 0.7 \\
\hline & Pharmacist & 0 & 0.0 \\
\hline & Transfer & 6 & 2.2 \\
\hline & By himself/herself & 34 & 12.3 \\
\hline & Other & 10 & 3.6 \\
\hline \multirow{2}{*}{ Post-application health problem } & Yes & 2 & 2.3 \\
\hline & No & 86 & 97.7 \\
\hline \multirow{3}{*}{ Benefit from the application } & Complete & 16 & 18.0 \\
\hline & Partial & 64 & 71.9 \\
\hline & None & 9 & 10.1 \\
\hline \multirow{2}{*}{ Repeating application } & Yes & 52 & 59.1 \\
\hline & No & 36 & 40.9 \\
\hline \multirow{2}{*}{ Recommending the app } & Yes & 66 & 76.7 \\
\hline & No & 20 & 23.3 \\
\hline
\end{tabular}

\footnotetext{
*More than one option ticked. Percentage is taken over the total number.
} 
Volume: 2 Issue: 3

Year: 2021

DOI: $10.53811 /$ ijtcmr.1008027
International Journal of Traditional and Complementary

Medicine Research
Publisher

Duzce University
The CACMAS mean score of the participants was found to be $109.05 \pm 15.44$ (Table 3). Distribution of people using TMC according to the treatment modality they use is shown in Figure 1.

Table 3. The mean and standard deviation of the participants' scores on the Complementary, Alternative, and Conventional Medicine Attitude Scale (CACMAS)

\begin{tabular}{lc}
\hline Scale total score & $\begin{array}{c}\text { Mean } \pm \text { standard } \\
\text { deviation }\end{array}$ \\
\hline $\begin{array}{l}\text { Philosophical congruence } \\
\text { with complementary and } \\
\text { alternative medicine }\end{array}$ & $109.05 \pm 15.44$ \\
\hline $\begin{array}{l}\text { Dissatisfaction with } \\
\text { conventional medicine }\end{array}$ & $46.57 \pm 8.11$ \\
\hline Holistic balance & $26.28 \pm 9.73$ \\
\hline
\end{tabular}

When the scores of the participants from the CACMAS were analyzed according to their sociodemographic characteristics, the mean score of the scale was $97.4 \pm 17.4$ in individuals aged 18$24,97.0 \pm 18.7$ in individuals aged 25-44, and $102.7 \pm 17.2$ in individuals aged 45 and over
( $\mathrm{p}=0.048)$. There was no statistically significant difference between gender, educational status, perceived income, marital status, family type, perceived health, presence of chronic disease and scale score $(p>0.05)$. When the sociodemographic variables associated with performing at least one application were compared, it was found that $29.2 \%$ of the participants aged $18-24,24.1 \%$ of the participants aged $25-44$, and $46.7 \%$ of the participants aged 45 and above performed at least one TCM application. ( $\mathrm{p}=0.002) .28 .5 \%$ of the participants whose place of residence was most of time city center for the longest time and $42.7 \%$ of those whose place of residence was most of time the county-town-village for the longest time stated that they used at least one TCM method $(p=0.019)$. There was no statistically significant difference between the characteristics of the participants such as gender, educational status, income, family type, and presence of chronic disease and use of at least one TCM method ( $p>0.05)$. The comparison of the participants' sociodemographic characteristics and their behaviors and attitudes towards TCM applications is given in Table 4.

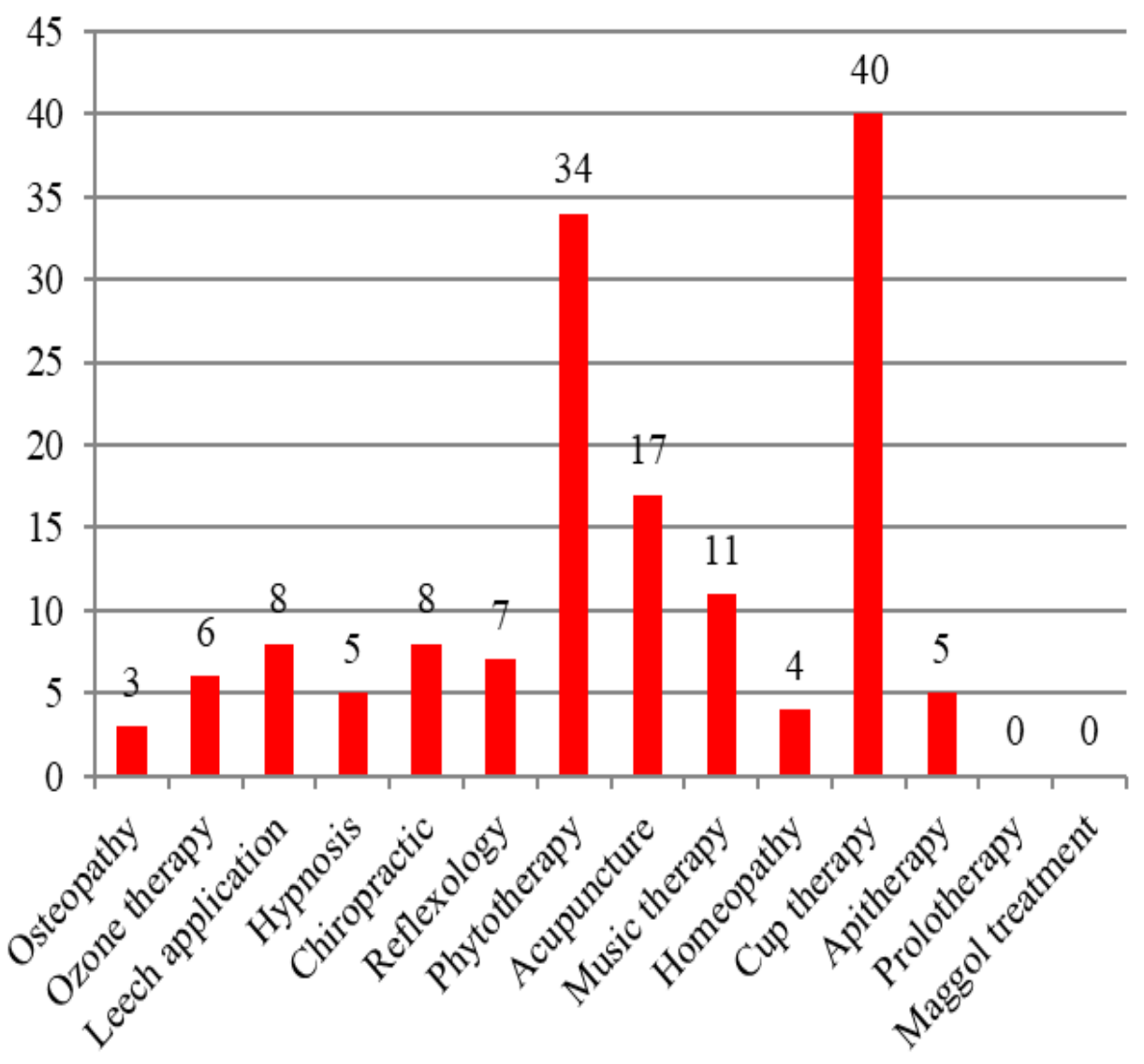

Applied TCM methods

Figure 1. Distribution of people using TMC according to the treatment modality they use. 
Volume: 2 Issue: 3

Year: 2021

DOI: $10.53811 /$ ijtcmr.1008027

Table 4. Comparison of the sociodemographic characteristics of the participants and their behaviors and attitudes towards TMC applications

\begin{tabular}{|c|c|c|c|c|}
\hline \multirow{2}{*}{ Variables } & & \multirow[b]{2}{*}{ Scale total score } & \multicolumn{2}{|c|}{ TCM } \\
\hline & & & Applying & Not applying \\
\hline Age & $\begin{array}{l}18-24 \\
25-44 \\
\geq 45 \text { years }\end{array}$ & $\begin{array}{c}97.4 \pm 17.4 \\
97.0 \pm 18.7 \\
102.7 \pm 17.2 \\
\mathbf{p}=\mathbf{0 . 0 4 8} \\
\end{array}$ & $\begin{array}{l}21(29.2) \\
27(24.1) \\
43(46.7) \\
\mathbf{p}=\mathbf{0 . 0 0 2} \\
\end{array}$ & $\begin{array}{l}51(70.8) \\
85(75.9) \\
49(53.3)\end{array}$ \\
\hline Gender & $\begin{array}{l}\text { Female } \\
\text { Male }\end{array}$ & $\begin{array}{c}99.83 \pm 18.04 \\
97.88 \pm 18.11 \\
(\mathrm{p}=0.380) \\
\end{array}$ & $\begin{array}{l}57(35.2) \\
33(29.2) \\
\mathrm{p}=0.298\end{array}$ & $\begin{array}{l}105(64.8) \\
80(70.8)\end{array}$ \\
\hline Education level & $\begin{array}{l}\text { Middle school and below } \\
\text { High school and above }\end{array}$ & $\begin{array}{c}98.28 \pm 17.34 \\
99.19 \pm 18.19 \\
p=0.772\end{array}$ & $\begin{array}{l}17(37.8) \\
74(32.0) \\
\mathrm{p}=0.453\end{array}$ & $\begin{array}{l}28(62.2) \\
157(68.0)\end{array}$ \\
\hline $\begin{array}{l}\text { Perceived } \\
\text { income }\end{array}$ & $\begin{array}{l}\text { Income less than expenses } \\
\text { Income equals expense } \\
\text { Income more than expenses }\end{array}$ & $\begin{array}{c}99.72 \pm 16.10 \\
98.45 \pm 19.10 \\
100.37 \pm 18.57 \\
\mathrm{p}=0.770\end{array}$ & $\begin{array}{l}31(37.3) \\
40(29.6) \\
20(37.0) \\
\mathrm{p}=0.414\end{array}$ & $\begin{array}{l}52(62.7) \\
95(70.4) \\
34(63.0)\end{array}$ \\
\hline Marital status & $\begin{array}{l}\text { Married } \\
\text { Single } \\
\text { Divorced/Widowed/Separate }\end{array}$ & $\begin{array}{c}100.4 \pm 17.8 \\
97.7 \pm 18.5 \\
99.3 \pm 16.5 \\
\mathrm{p}=0.483\end{array}$ & $\begin{array}{l}50(42.0) \\
33(25.2) \\
8(30.8) \\
\mathbf{p}=\mathbf{0 . 0 1 8}\end{array}$ & $\begin{array}{l}69(58.0) \\
98(74.8) \\
18(69.2)\end{array}$ \\
\hline Family type & $\begin{array}{l}\text { Nuclear family } \\
\text { Extended family } \\
\text { Broken family }\end{array}$ & $\begin{array}{c}98.63 \pm 18.00 \\
102.16 \pm 19.23 \\
98.92 \pm 17.69 \\
p=0.597\end{array}$ & $\begin{array}{l}74(32.2) \\
10(32.3) \\
5(38.5) \\
\mathrm{p}=0.895\end{array}$ & $\begin{array}{l}156(67.8) \\
21(67.7) \\
8(61.5)\end{array}$ \\
\hline $\begin{array}{l}\text { Longest lived } \\
\text { place }\end{array}$ & $\begin{array}{l}\text { Province } \\
\text { District/Town/Village }\end{array}$ & $\begin{array}{c}99.02 \pm 17.82 \\
99.14 \pm 18.65 \\
p=0.959\end{array}$ & $\begin{array}{l}53(28.5) \\
38(42.7) \\
\mathbf{p}=\mathbf{0 . 0 1 9}\end{array}$ & $\begin{array}{c}133(71.5) \\
51(57.3)\end{array}$ \\
\hline $\begin{array}{l}\text { Perceived } \\
\text { health }\end{array}$ & $\begin{array}{l}\text { Excellent/Very good } \\
\text { Good/Medium/Bad }\end{array}$ & $\begin{array}{c}97.3 \pm 20.1 \\
99.8 \pm 16.9 \\
p=0.291 \\
\end{array}$ & $\begin{array}{l}21(23.9) \\
70(37.2) \\
\mathbf{p}=\mathbf{0 . 0 2 8}\end{array}$ & $\begin{array}{c}67(76.1) \\
118(62.8)\end{array}$ \\
\hline Chronic disease & $\begin{array}{l}\text { Yes } \\
\text { No }\end{array}$ & $\begin{array}{c}98.97 \pm 16.45 \\
99.02 \pm 18.96 \\
p=0.852\end{array}$ & $\begin{array}{l}40(39.6) \\
51(29.3) \\
p=0.080\end{array}$ & $\begin{array}{c}61(60.4) \\
123(70.7)\end{array}$ \\
\hline $\begin{array}{l}\text { Outpatient } \\
\text { clinic applied }\end{array}$ & $\begin{array}{l}\text { Internal medicine } \\
\text { Family medicine } \\
\text { Dermatology } \\
\text { Physical therapy and rehabilitation }\end{array}$ & $\begin{array}{c}101.35 \pm 16.41 \\
100.11 \pm 19.62 \\
106.00 \pm 20.46 \\
99.04 \pm 18.03 \\
\mathbf{p}=\mathbf{0 . 0 1 0}\end{array}$ & $\begin{array}{l}29(33.0) \\
10(43.5) \\
25(35.2) \\
27(28.7) \\
\mathrm{p}=0.556 \\
\end{array}$ & $\begin{array}{l}59(67.0) \\
13(56.5) \\
46(64.8) \\
67(71.3)\end{array}$ \\
\hline
\end{tabular}

\section{DISCUSSION}

This research was conducted to determine the knowledge, attitudes and behaviors of people who applied to the polyclinics of a university hospital towards TCM methods. In the study, it was determined that the majority of the participants had heard of TCM methods, nearly half of them were informed about the methods, and one third of them applied at least one method while $85 \%$ of the participants have heard of TMC methods. In the study conducted by Sensoy et al. ${ }^{14}$ among those who applied to a university hospital, 95\% of the participants were aware of TCM practices, while in the study conducted by Ozer et al. ${ }^{3} 68.5 \%$ of the patients were knowledgeable about TCM methods ${ }^{3}$. In the present study, the most common source of information about TCM was television/radio/internet; it was determined that neighbor/friend/relative is in the second rank. It is thought-provoking that the frequency of obtaining information from health personnel is quite low. Similar to our research finding, in the study conducted by Odabas and Agadayi ${ }^{15}$, it was the media from which participants get the most information with a frequency of $64 \%$, and the least information from the doctors. In the study conducted by Sensoy et al. ${ }^{14}$, participants received information from their close circles with a frequency of $76.9 \%$ and from the media with a frequency of $15.9 \%$. According to the study conducted by Karatas et al. ${ }^{16}$, the most common source of information about the TCM 


\author{
Volume: 2 Issue: 3 \\ Year: 2021 \\ DOI: $10.53811 /$ ijtcmr.1008027
}

International Journal of Traditional and Complementary

Medicine Research
Publisher
Duzce University methods of the participants during the Covid 19 pandemic process is social media $(52.4 \%)$, while the second most frequent is close relatives, friends and neighbors $(27.5 \%)$. The reason for the low frequency of obtaining information from health personnel may be negative reactions and disapproval 3,17. Information about the correct application of TCM methods, interactions with ongoing medical treatment, and whether the method is suitable for the patient should be obtained from the doctor ${ }^{7}$.

It can be said that the attitudes of the individuals participating in our research towards alternative medicine methods are moderately positive according to the scale score average. It can be stated that the participants of the research approached complementary medicine practices cautiously.

In the study conducted by Ozer et al. ${ }^{3}$, on patients who applied to the internal medicine outpatient clinic using CACMAS, the mean score of the scale was found $115.78 \pm 18.81$, and it was stated that the participants' attitudes towards TCM were moderately positive. The average score $(29.52 \pm 5.70)$ obtained in the study conducted by Sensoy et al. ${ }^{14}$, using the Attitude Scale to Integrative Complementary and Alternative Medicine (ICTAS) indicates that the participants' attitudes towards traditional and complementary medicine are moderately positive. In the study conducted by Dursun et al. ${ }^{18}$, the mean CACMAS score was found to be $103.99 \pm 22.03$, similar to our study.

In this study, it can be said that the attitudes of people aged 45 and above more positive towards TCM methods than those in the other age groups. In the study conducted by Ozer et al. ${ }^{3}$, no significant correlation was found between the CACMAS score and age.

Most of the people with chronic diseases in Turkey use at least one TCM method and the most commonly used methods are herbal therapy, massage and acupuncture ${ }^{17}$. In the study, one third of the participants used at least one TCM method and the most used methods as cupping, phytotherapy and acupuncture. Dursun et al. ${ }^{18}$ reported that the frequency of using traditional complementary medicine in individuals aged 18-65 who applied to the family health center was $39.3 \%$, similar to our study. The most commonly used methods in this study are herbal therapy, massage, and cupping. In the study conducted by Odabas and Agadayi ${ }^{15}$, on patients who applied to the family health center, $14.8 \%$ of the participants used at least one TMC method, the most common being mug, leech and acupuncture. According to the research conducted by Ozer et al. ${ }^{3}, 56.5 \%$ of the participants used at least one TCM method. Avci ${ }^{19}$ reported that $46.4 \%$ of diabetic patients who applied to university hospital outpatient clinics used at least one TCM method.

In a study evaluating data from 32 countries, the frequency of use of TMC has been reported as $33.2 \%$ in the USA, $0.3-86.0 \%$ in Europe, $76.0 \%$ in Japan, $71.3 \%$ in South Korea, and $22.1 \%$ in Turkey. TCM is applied the most in China $(50.7 \%)$ and the least in Poland $(6.1 \%)^{10} .30 \%$ of cancer patients in Europe and $33.4 \%$ in Norway reported using TMC in the last one year ${ }^{20}$.

In the present study, it was found that the participants used TCM methods with a frequency of $66.3 \%$ for relaxation. In the study conducted by Ozer et al. ${ }^{3}$, TCM methods were most frequently used to support a conventional treatment $(28.3 \%)$, and in the study conducted by Odabas and Agaday 15, 76.3\% used TCM to alleviate musculoskeletal pain.

In recent years, when chronic diseases have come to the fore and the proportion of the elderly population has increased, TCM applications could be the first treatment method applied ${ }^{21}$. As a matter of fact, TCM methods are mostly applied before visiting a doctor, though the use of TCM methods as an alternative to conventional medicine and the use of these methods without consulting a physician may cause delay in diagnosis and treatment ${ }^{21,22}$.

In our study, it was found that $66 \%$ of the people who are using TCM perform the application in their home environment and mostly apply it to themselves. In the study conducted by Odabas and Agadayi ${ }^{15}, 60.5 \%$ of those who had TCM had this application done at home. The application of these applications by people who have not been trained in TCM methods with unsuitable materials and under bad conditions may cause serious side effects ${ }^{22}$. With the "Regulation on Traditional and Complementary Medicine Practices", the principles of application, the situations in which the method should be applied, the characteristics of the practitioner, the medical materials and devices used during the treatment were determined $^{11}$.

According to the research, the majority of the participants $(97.7 \%)$ did not experience any side effects after the application, $71.1 \%$ benefited partially from the application, $59.1 \%$ repeated the application and $76.7 \%$ recommended the application to others. In the study conducted by Ozer et al. ${ }^{3}$, 


\author{
Volume: 2 Issue: 3 \\ Year: 2021 \\ DOI: $10.53811 /$ ijtcmr.1008027
}

International Journal of Traditional and Complementary

Medicine Research
Publisher
Duzce University
$58.9 \%$ of the participants recommend the method they use to others. In the study conducted by Avci ${ }^{19}$, $48.6 \%$ of diabetic patients did not report any side effects regarding the method they used, and $66.4 \%$ did not complain about the method they used. In the study conducted by Odabas and Agadayi ${ }^{15}, 70.3 \%$ of the participants stated that they benefited from their practice. Accordingly, it can be said that the majority of people who apply TCM find the methods useful and reliable, and are satisfied with the methods they use.

TCM methods are mostly applied by people aged 45 and over, married, living in rural areas, and people who do not consider their health as excellent or very good. It was found by Avci ${ }^{19}$ that diabetes patients aged 65 and over use TCM methods more frequently. In the study conducted by Karatas et al. ${ }^{16}$, people aged 40 and over and married people use these methods more frequently, similar to our research finding. In the study conducted by Otegen et al. ${ }^{23}$, people aged 40 and over use the interventional TCM method more. According to studies, TCM applications are more preferred by people who are elderly, live in rural areas, and have diseases that are difficult to treat and last for a long time ${ }^{22}$.

\section{Limitations and strengths of the research}

The research was conducted among patients who applied to selected polyclinics of a university hospital with various health problems and their relatives. Since it is a hospital-based study, the data do not fully reflect the attitudes and behaviors of the society towards traditional and complementary medicine.
Despite this, revealing the knowledge, attitudes and behaviors of individuals who apply to a health institution providing tertiary treatment services towards traditional and complementary medicine methods can be a guide for health service providers. Attitudes of the participants were measured with a scale with proven validity and reliability. $72.0 \%$ of the sample size determined at the beginning of the research has been reached.

\section{CONCLUSION}

TCM methods are known to the majority of people who visit selected polyclinics of an university hospital and are applied by one third of them. Individuals generally apply these methods without consulting health personnel but with the information which they receive from the media and their close circles. The attitudes of the participants towards TCM applications are quite close to positive. Physicians should question the TCM methods used by patients to prevent undesirable interactions before prescribing medication. Health professionals should provide counseling to individuals who apply to them about TCM.

\section{ACKNOWLEDGEMENTS}

We are grateful to Ozlem Guler, Emine Aslı Akdeniz, Ecem Ertemir, Mustafa Arıc1, Muharrem Ozer Basturk, Engin Deniz Oytun, Emre Can Topcu, Mehmet Ozer, Irmak Kırcicegi Onal, Selin Cınar, Gizem Seven and Halil Hakan Akman for the help during data collection.

\section{REFERENCES}

1. http:// apps. who. int/iris/ bitstream/ 10665/92455/ 1/9789241506090_eng. pdf? ua=1 2013. Date of access: 08/10/2021.

2. https://apps.who.int/iris/handle/10665/67163. Date of access: 08/10/2021.

3. Zülfünaz Ö, Turan GB, Bakır E. Dahiliye Polikliniğine Başvuran Hastaların Geleneksel ve Tamamlayıcı Tıbba Karşı Tutumları ve Etkileyen Faktörler. Sağllk Profesyonelleri Araştırma Dergisi. 2020;2(3):102-112.

4. Singh A, Kamath A. Attitude of Medical Students and Doctors towards Complementary, Alternative and Integrative Medicine: A Single-Center, Questionnaire-Based Study. J Pharmacopuncture. 2021;24(2):84-90.

5. Samara AM, Barabra ER, Quzaih HN, Zyoud SH. Use and acceptance of complementary and alternative medicine among medical students: a cross sectional study from Palestine. BMC Complement Altern Med. 2019;19(1):78.

6. Kavadar G, Eroğlu Demir S, Aytekin E, Akbal Y. Use of traditional and complementary medicine for musculoskeletal diseases. Turk J Med Sci. 2019;49(3):809-814.

7. Tangkiatkumjai M, Boardman H, Walker DM. Potential factors that influence usage of complementary and alternative medicine worldwide: a systematic review. BMC Complement Med Ther. 2020;20(1):363.

8. Berna F, Göritz AS, Mengin A, Evrard R, Kopferschmitt J, Moritz S. Alternative or complementary attitudes toward alternative and complementary medicines. BMC Complement Altern Med. 2019;19(1):83.

9. Mwaka AD, Tusabe G, Garimoi CO, Vohra S, Ibingira C. Integration of traditional and complementary medicine into medical school curricula: a survey among medical students in Makerere University, Uganda. BMJ Open. 2019;9(9):e030316. 
Volume: 2 Issue: 3 Year: 2021 DOI: $10.53811 /$ ijtcmr.1008027
Medicine Research
Publisher

Duzce University

10. Misawa J, Ichikawa R, Shibuya A, Maeda Y, Arai I, Hishiki T, Kondo Y. The impact of uncertainty in society on the use of traditional, complementary and alternative medicine: a comparative study on visits to alternative/traditional/folk health care practitioners. BMC Complement Altern Med. 2019;19(1):251.

11. Resmi Gazete. Geleneksel ve Tamamlayıcı Tıp Uygulamaları Yönetmeliği. 27.10.12014; Sayı: 29158. Date of Access: 20/11/2021.

12. Grace R, Vaz J, Da Costa J. Traditional medicine use in Timor-Leste. BMC Complement Med Ther. $2020 ; 20(1): 165$.

13. Köse E, Ekerbiçer HÇ, Erkorkmaz Ü. Complementary, Alternative and Conventional Medicine Attitude Scale: Turkish Validity Reliability Study. Sakarya Tip Dergisi. 2018;8(4):726-736.

14. Şensoy N, Özdinç Ş, Yılmaz O, Çetin MD, Dilara T, Doğantekin P, Erden B, Güler K. Üniversite Hastanesine Başvuran Hastaların Tamamlayıcı ve Alternatif Tedavi Kullanımına Yönelik Tutum ve Davranışları. Kocatepe Tip Dergisi. 2020;21(3):258-263.

15. Odabaş ÖK, Ağadayı E. Aile Hekimliği Polikliniğine Başvuran Hastaların Geleneksel ve Tamamlayıcı Tıp Uygulamaları Hakkında Bilgi ve Davranışları. TJFMPC. 2021;15(1):121-128.

16. Karataş Y, Khan Z, Bilen Ç, Boz A, Özagil ESG, Abussuutoğlu AB, Rahman H. Traditional and Complementary Medicine use and beliefs during COVID-19 outbreak: A cross-sectional survey among the general population in Turkey. Adv Integr Med. 2021.

17. Akan H, Izbirak G, Kaspar EC, Kaya CA, Aydin S, Demircan N, Bucaktepe PG, Ozer C, Sahin HA, Hayran O. Knowledge and attitudes towards complementary and alternative medicine among medical students in Turkey. BMC Complement Altern Med. 2012;12:115.

18. Dursun S, Vural B, Keskin B, Kaçar H, Beyhan A, Kadığlu H. The relationship between traditional/complementary medical attitude and health literacy and health perception in adults. J Public Health Nurs. 2019;1(1):1-10.

19. Avci DK. The use of traditional and complementary medicine among diabetes patients, and the awareness and attitudes of physicians. J Pak Med Assoc. 2018;68(11):1650-1654.

20. Horneber M, Bueschel G, Dennert G, Less D, Ritter E, Zwahlen M. How many cancer patients use complementary and alternative medicine: a systematic review and metaanalysis. Integr Cancer Ther. 2012;11(3):187-203.

21. Lakshmi JK, Nambiar D, Narayan V, Sathyanarayana TN, Porter J, Sheikh K. Cultural consonance, constructions of science and co-existence: a review of the integration of traditional, complementary and alternative medicine in low- and middle-income countries. Health Policy Plan. 2015;30(8):1067-1077.

22. Öztürk YE, Dömbekci HA, Ünal SN. Geleneksel Tamamlayıcı ve Alternatif Tıp Kullanımı. Bütünleyici ve Anadolu Tıbbı Dergisi. 2020;1(3):23-35.

23. Ötegen E, Başer DA, Kecik H, Aksoy H, Fidanci I. Attitudes and Behaviors of Adults on Interventional (Invasive) Traditional Medicine Methods: A Descriptive Study. IJTCMR. 2021;2(02):62-68. 